\title{
The Implications of Modifying Traffic Circulation Down Town Amman CITY
}

\author{
Wael H. 'Awad \\ wawad@ammanu.edu.jo
}

\begin{abstract}
Associate Professor, Department of Civil Engineering Dean of Engineering, Al-Ahliyya Amman University On sabbatical leave from Al Balqa' Applied University Amman, Jordan
\end{abstract}

\begin{abstract}
Urban regeneration requires collaboration of traffic engineers with urban planners and architects to provide decision makers with quantitative assessment of the impact of attempted changes in the urban setting. Simulating traffic is a very powerful assessment tool for both traffic engineers and urban planners to help decision makers in selecting the best alternative solution based on predefined criteria while saving resources with high level of precision and accuracy. In this research paper, six action plans were suggested: provide better pedestrian facilities; provide better parking facilities; organize loading and unloading operations; relocate terminals and public transport routes; propose new circulation plan; and relocate the Police Station on Faisal Street. In accordance with all actions, an optimal traffic circulation scenario (new circulation plan) was compared to the do-nothing circulation scenario (current circulation plan). Macro and micro measures of effectiveness are used to quantitatively compare between the two scenarios. Results showed notable improvements in favor of the proposed new circulation plan; however traffic conditions are expected to significantly improve if the demand implications of adopting the other actions were considered.
\end{abstract}

KEYWORDS: traffic circulation, urban regeneration, demand management, traffic simulation.

$$
\text { تأثير تعديل التقاطعات المروربة لمركزمدينة عمان }
$$

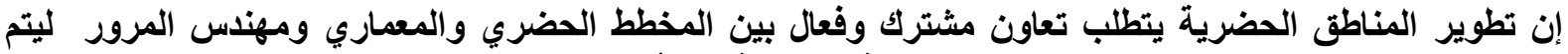

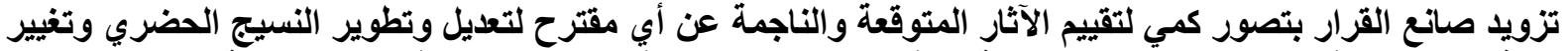

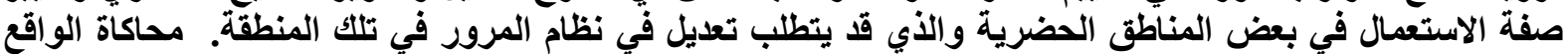

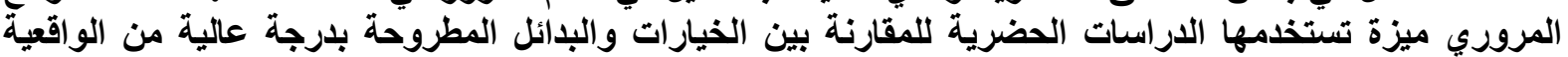

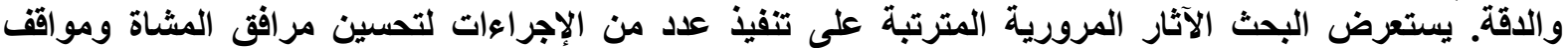

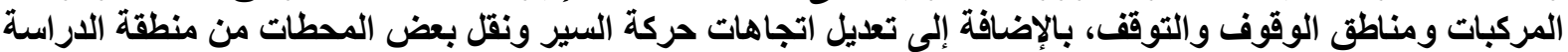

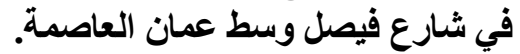

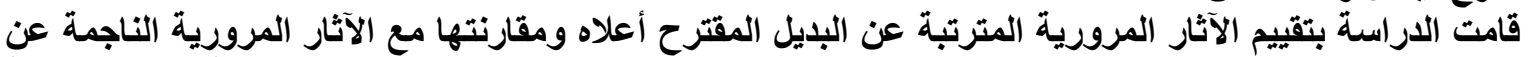

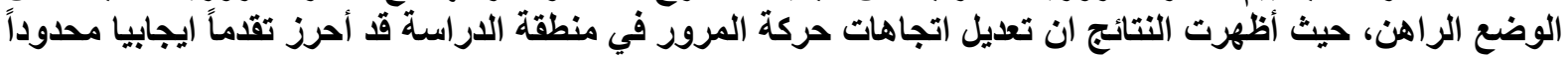

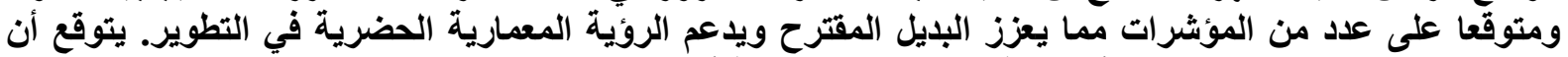
تزداد إيجابيات البديل المقترح عند أخذ كافة الإجراءات المقائ المقترحة أعلاه بعين الاعتبار. 


\section{Introduction and Background}

Decisions to modify traffic circulation plans inside cities are not purely a technical issue and they are definitely challenging. Politically, it might cost the decision maker his/her position if results did not go their way. Back in the 80's of past century, before simulation models became a common practice; decision makers kept circulation modification to the minimum, and the opportunities for public participation were limited (TSUBOHARA, S. 2007). Comprehensive urban planning is the key to successful decisions; and transportation planning takes place within that context among other types of planning; such as land use planning and environmental planning (Kelly, E.D., 2010). Greater Amman Municipality (GAM) developed its own comprehensive master plan (GAM, 2012) to facilitate such decisions, and provide tools to assure harmony between land use at one end and traffic demand/supply at the other end.

Now a day, traffic simulation models provided researcher with wonderful tool to explore the expected outcomes of various circulation plans with high level of reliability and confidence. Microscopic traffic simulation models are widely used to evaluate traffic circulation plans; road features' changes; and other traffic policies with less time; less cost; and faster than actual field implementations (Wonkyu K. et. al., 2010). Transportation management systems and transportation demand management (TDM) approaches support low cost solutions as long as they will pay off. However, reliable performance measures must be employed to indicate the effectiveness of alternative proposals (Thompson, et al. 2012). Simulation tools have wide spectrum of measures of effectiveness to support decision making process including measures of emissions; measures of pollutions; measures of fuel consumption; and measures of delay.

Active transportation and demand management (ATDM) measures (Dowling, R. et al. 2011) is a comprehensive management and operation approach aims at increasing the facility productivity by proactively reaching supply/demand balance. Employing one or more of the ATDM measures; such as adaptive ramp metering; speed management; work zone management, and traffic signal control systems can be evaluated using HCS or micro simulation tools.

Impacts of urban regeneration projects on traffic conditions impose an imminent collaboration between urban planner and traffic engineering. Urban planner and architects considered the regeneration of down town Amman area to bring back life to this ancient historical part of the city, and support the added value of the space by providing attractive safe space to pedestrians; shoppers; tourists; and commuters. Part of the urban regeneration plan of the study area was to examine different traffic circulation plans. This paper proposes a practical tool box of actions to elevate traffic conditions in the study area and simulate traffic for various traffic circulation plans.

An experiment on part of a local network in the vicinity of Mutah University in Jordan employed a multi agent traffic simulation tool for micro and macro simulation (Al-Dmour, N. A., 2011) to study the traffic behavior. Results compared among various features such as car following; lane-changing, traffic lights, and journey times under varying traffic conditions. In another study (Alami, A. H., 2011) utilized finite element simulation tool to simulate traffic flow at a busy street in Amman, Jordan to predict traffic patterns on that link. The developed model showed an acceptable degree of conformance to actual observations.

This research paper is intended to set the base for more local work towards the collaboration and integration among urban planners; architects, and traffic engineers in Jordan to encourage more local publications to spread the culture of the common international practice in utilizing 
traffic simulation to help local decision makers and provide them with reliable quantitative measures.

\section{Case Study}

The backbone street of the down town area of Amman city, the capital of Jordan is Faisal Street, a two-way urban street with two lanes per direction connecting King Talal Street with Al-Salt Street. Faisal Street is only few hundred meters in length running north south. Two parallel streets on both sides of Faisal Street are one-way streets running south-north work as feeders to relief traffic congestion on Faisal Street and provide other options to commuters. Ghazi Street (east of Faisal Street) goes north bound while Bassman Street (west of Fasial Street) is partially one-way goes north bound (Figure 1).

In a previous study ('Awad, 2012), based on existing traffic condition of the study area and the perception of commuters and

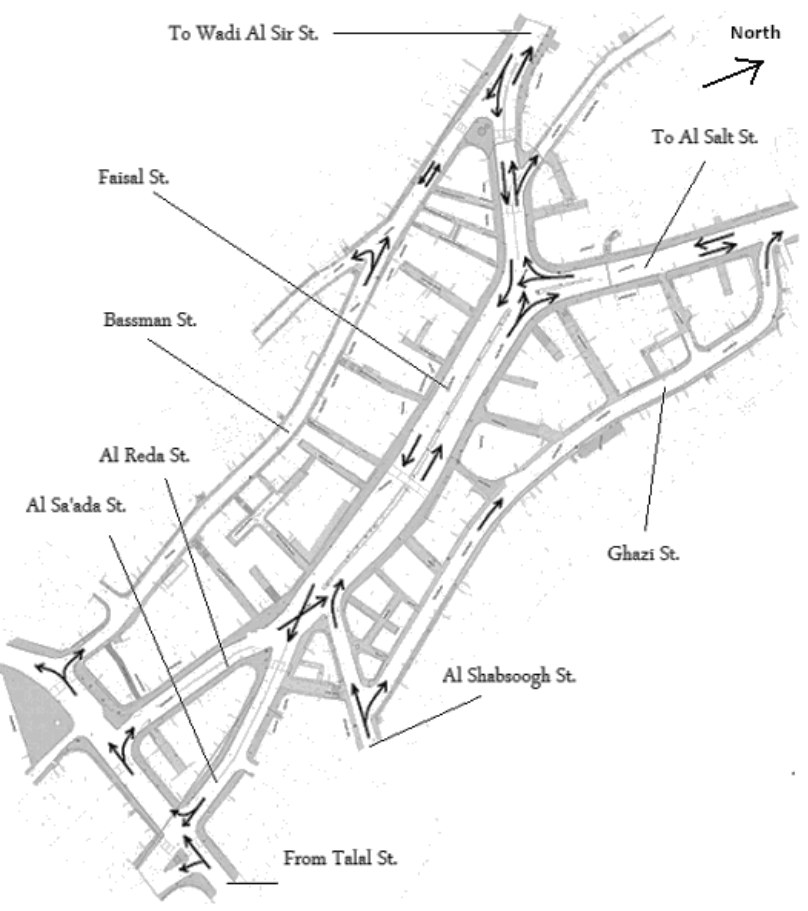

Figure 1: Faisal Street and Surroundings workers, a set of actions to redevelop the study area and elevate the congestion problem (defined and quantified later as Do-Nothing scenario) were suggested. The actions were ranked as followed:

1. Pedestrian facilities and circulation.

2. Parking facilities.

3. Loading and unloading areas.

4. Public transport routes and terminals.

5. Circulation of traffic and quality of service for the traffic flow.

The above ranking is purely representing the stakeholders point views to match their common interests indicating the needs for keeping some public transport routes and terminals within Faisal Street to maintain its livability, with less emphasis on the traffic condition and circulation. Anticipating the future regeneration of Faisal Street, the following actions are considered while developing scenarios:

\section{Action I: Provide better pedestrian facilities}

a. Either South bound or North bound direction of Faisal Street needs to be switched for pedestrians with a total width of 10 meters minimum (taking 8 meters from carriage way), and reduce the sidewalk width of the other bound to 2 meters.

b. Prohibit random pedestrian crossings, and designate proper crossings at three specific locations (one at each end of Faisal, and one in the middle).

c. Provide handicapped facilities. 
2. Action II: Provide better parking facilities

a. Develop one multi-story (multi-purpose) building on Ghazi Street (accessible from the castle -Al-Qala'a- Street) with parking facilities, hotel, shops, and other uses.

b. Prohibit on-street parking on Faisal, Ghazi, and Bassman Streets.

c. Regulate on-street parking on adjacent streets surrounding the study area.

d. Develop surface parking lots away from down town (called Park and Ride lots, suggested locations are near GAM headquarters, near old Ragadan terminal, and near Samir Refa'e school (Figure 2) with free shuttle services to and from down town area.

3. Action III: Organize loading and unloading operations

a. Provide designated areas for commercial operations on Faisal, Ghazi, and Bassman Streets (either on-streets or utilizing the alleys in between).

b. Provide stations for loading and unloading passengers.

4. Action IV: Relocate terminals and public transport routes

a. Remove terminals from Faisal, Ghazi, and Bassman Streets.

b. Make uses of alleys next to the above streets wherever possible to store some of the necessary terminals, and relocate others to Ragadan terminal.

c. Any complete solution in the future should be based on a comprehensive study for the public transport system in the down town area.

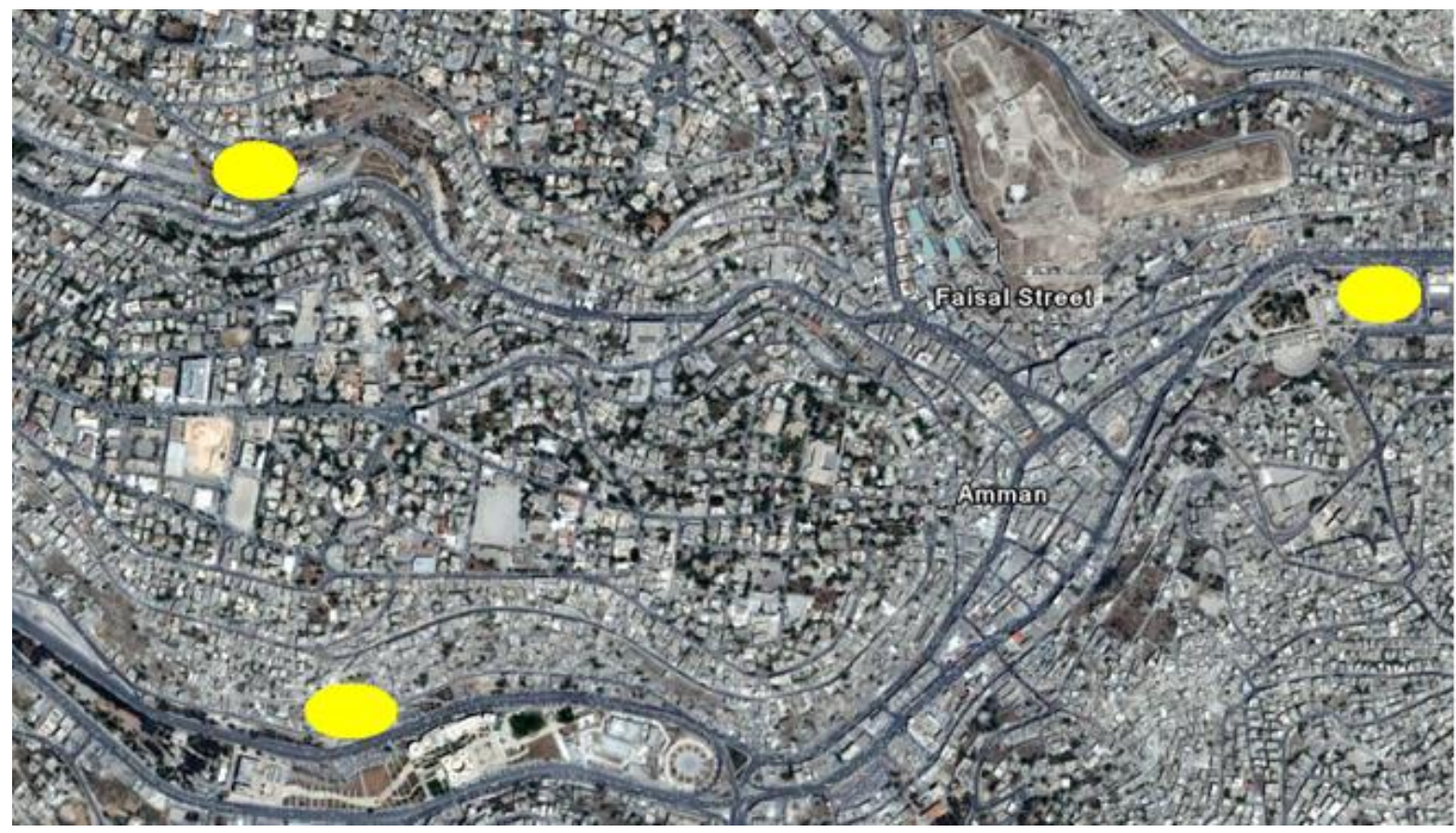

Figure 2: Proposed Locations for Park and Ride Facilities (North up)

5. Action V: Propose new circulation plan for the study area

a. Convert the traffic on Faisal Street to one-way south bound on the original north bound direction, and keep traffic moving north bound on Ghazi and Bassman Streets. 
b. Remove the signals at two junctions and keep the one on the far south of Faisal Street at the end on Al Reda Street.

c. Install a roundabout at the far north of Faisal Street instead of the signal.

d. Install two new signals at the north end junction of Bassman and at the north end junction of Ghazi Street.

e. Provide a cross section of 4-lanes on Faisal Street for through traffic (12 meters) South bound, and 2-lanes on Ghazi and Bassman Streets (6 meters) North bound, leaving rooms for loading and unloading (Action III).

6. Action VI: Relocate the Police Station on Faisal Street.

\section{Scenario Development}

Based on the above, many preliminary circulation scenarios are examined against the existing circulation scenario and against each others. The following qualitative criteria are considered to evaluate and refine scenarios: pedestrian safety; vehicle access; traffic operation; public transit operation; down town connectivity; down town identity and land use pattern. At the beginning, the following circulation scenarios were considered: one-way versus two-way on Faisal Street; switching movement directions; switching sides of pedestrian movements; and modifying control system at intersections.

The final examined circulation plan (new circulation plan) is a refined scenario that will be farther considered and examined against the do-nothing scenario.

\section{Scenario Description}

The two examined circulation plans are the do-nothing conditions and the new circulation plan are described in Figures 3 and 4, respectively. Table 1 summarizes the differences between the two examined scenarios.

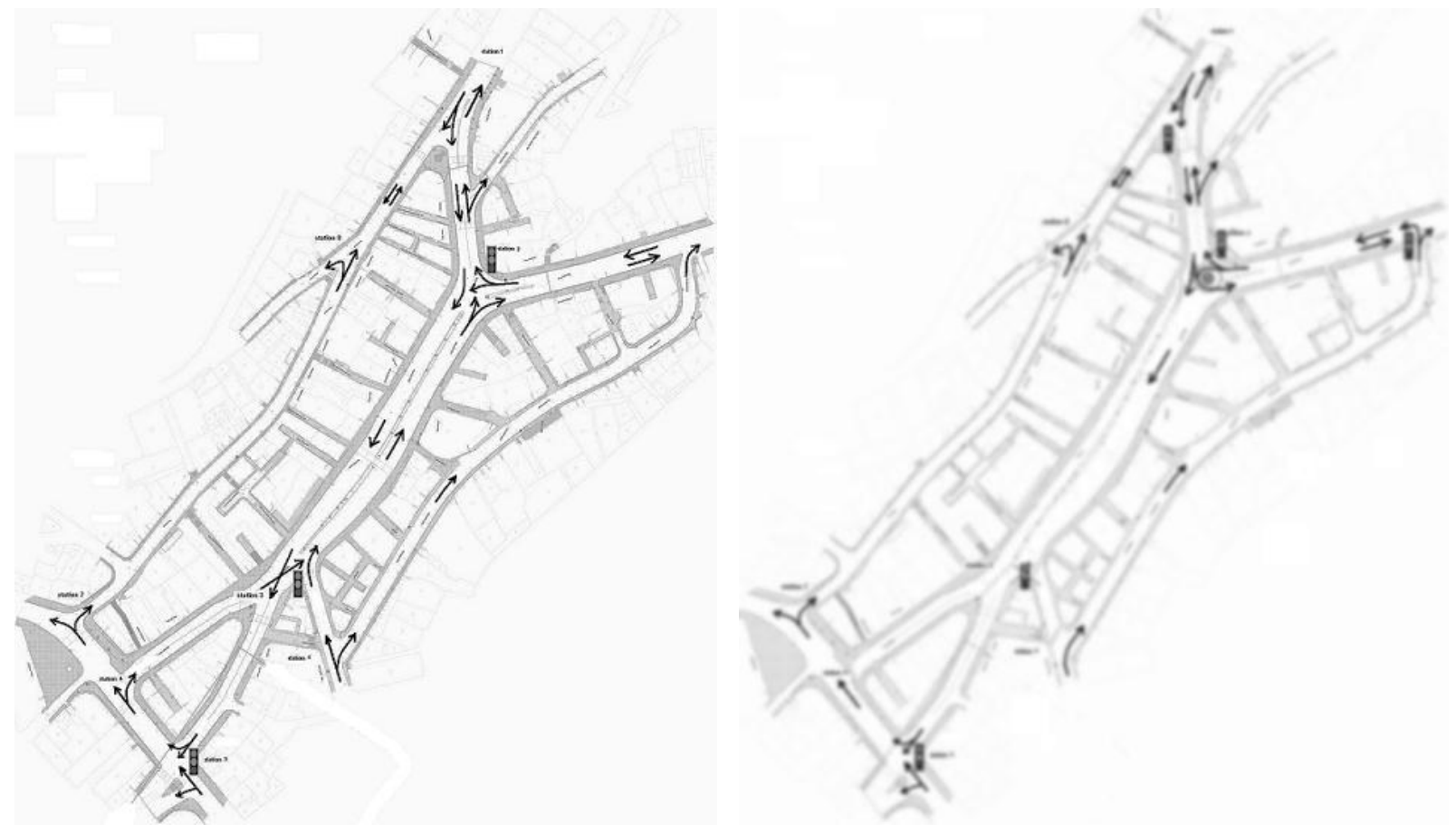

Figure 3: Do-nothing Circulation Plan

Figure 4: New Circulation Plan 
Table 1: Feature Changes for New Circulation

\begin{tabular}{|c|c|c|c|}
\hline \multicolumn{2}{|c|}{ Geometric/Control Feature } & Existing Circulation & NewCirculation \\
\hline \multirow{4}{*}{ 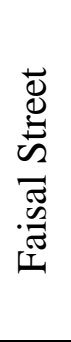 } & Traffic carriage way & Two Way & $\begin{array}{l}\text { One Way (South Bound) on the } \\
\text { eastside of Faisal }\end{array}$ \\
\hline & Pedestrian Sidewalks & $\begin{array}{l}\text { Both sides } \\
\text { (approximately equal } \\
\text { widths) }\end{array}$ & $\begin{array}{l}\text { Both sides (switching part of the } \\
\text { Westside traffic carriage way to } \\
\text { pedestrian sidewalk) }\end{array}$ \\
\hline & Pedestrian crossings & Random & Controlled \\
\hline & Parking & Random & Controlled \\
\hline \multicolumn{2}{|c|}{ Ghazi Street } & One Way (North Bound) & One Way (North Bound) \\
\hline \multicolumn{2}{|c|}{ Bassman Street } & $\begin{array}{l}\text { Partially One Way } \\
\text { (North Bound) }\end{array}$ & Partially One Way (North Bound) \\
\hline \multicolumn{2}{|c|}{ AL Shabsoogh Street } & One Way & Pedestrian sidewalk \\
\hline \multicolumn{2}{|c|}{ Al Reda Street } & One Way (Northbound) & Pedestrian sidewalk \\
\hline \multicolumn{2}{|c|}{ Al Sa'ada Street } & One Way (Southbound) & One Way (Southbound) \\
\hline \multirow{7}{*}{ 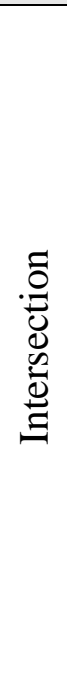 } & $\begin{array}{l}\text { AL Salt Street \& } \\
\text { Ghazi Street }\end{array}$ & $\begin{array}{l}\text { Unsignalized (right turn } \\
\text { only from Ghazi Street) }\end{array}$ & $\begin{array}{l}\text { Signalized (right and left turns } \\
\text { from Ghazi Street) }\end{array}$ \\
\hline & $\begin{array}{l}\text { Wadi Al Sir Street \& } \\
\text { Bassman Street }\end{array}$ & Unsignalized & Signalized \\
\hline & $\begin{array}{l}\text { AL Salt Street \& } \\
\text { Faisal Street }\end{array}$ & Signalized & Roundabout \\
\hline & $\begin{array}{l}\text { Faisal Street \& AL } \\
\text { Shabsoogh Street }\end{array}$ & Signalized & Remove intersection \\
\hline & $\begin{array}{l}\text { Faisal Street (Al } \\
\text { Sa'ada) \& Talal Street }\end{array}$ & Signalized & Signalized \\
\hline & $\begin{array}{l}\text { Faisal Street (Al Reda) } \\
\& \text { Talal Street }\end{array}$ & Unsignalized & Remove intersection \\
\hline & $\begin{array}{l}\text { Talal Street \& } \\
\text { Bassman Street }\end{array}$ & Unsignalized & Unsignalized \\
\hline
\end{tabular}

Note: Unchanged features are shaded.

\section{Assumptions for Modeling}

In order to understand the effect on traffic due to the road network changes in the study area (new circulation plan and changes in geometric features by creating pedestrian pathway on Faisal Street) the scenarios mentioned above were analyzed. The existing circulation (donothing scenario) and the new circulation plan are evaluated after optimizing the signal timing at the three signalized intersection using Synchro on a network-wide basis (for the three periods; morning; mid day; and evening).

Utilizing the results of the origin-destination (OD) survey, the assumptions used to assign traffic for the new circulation plan are:

1. Traffic originally coming from Al Shabsoogh Street is totally switched to moving through Ghazi Street and distributed into right turns $(0.40)$ and left turns $(0.60)$ when intersecting with Al Salt Street. The justification of this assumption is based on the attractiveness of the other route via Bassman Street, which will reduce the proportion of left turns from (0.76 to 0.60$)$. 
2. Traffic originally coming from Wadi Al Sir Street will stay the same. However, the proportion going to AL Salt Street (0.15) will not go all the way through Faisal Street as before, it will turn left on the roundabout.

3. Traffic originally coming from Al Salt Street will stay the same, keeping in mind that more traffic is coming from Al Shabsoogh Street.

4. Traffic originally coming from Al Reda Street is partially split between Bassman Street (0.45) Street and Ghazi Street (0.45) to serve traffic going to Wadi Al Sir Street and Al Salt Street, respectively. The traffic originally going to Al Sa'ada Street will be limited to Taxicabs with (0.10) via Bassman Street with a total of (0.55).

5. Bassman Street played minor role in accommodating traffic in the existing circulation plan, and is anticipated to carry approximately 0.35 of the overall original north bound traffic on Faisal, while Ghazi Street is anticipated to carry approximately 0.50 of the overall original north bound traffic on Faisal, and the rest 0.15 is already distributed in point 2 above. The traffic on Bassman Street will be distributed at the northern end (signalized intersection) at the same original proportions on the northern bound of Faisal Street.

6. Due to the new circulation plan, Talal Street is anticipated to carry less traffic approaching Al Sa'ada Street since Ghazi Street is expected to attract some of the traffic going to Al Salt and Wadi Al Sir Streets.

7. As a worst case scenario, no reduction to traffic volumes is assumed due to the suggested management plans explained earlier (such as park and ride or relocating public transport terminals). Table 2 summarizes the splits.

Table 2: OD Survey Results

\begin{tabular}{|l|c|c|c|c|}
\hline \multicolumn{1}{|c|}{ From\To } & Wadi Al Sir St. & AL Salt St. & Al Sa'ada St. & Total \\
\hline Wadi Al Sir St. & & 0.036 & 0.200 & 0.24 \\
\hline AL Salt St. & 0.059 & & 0.160 & 0.22 \\
\hline AL Shabsoogh St. & 0.103 & 0.065 & 0.100 & 0.27 \\
\hline Al Reda St. & 0.078 & 0.081 & 0.120 & 0.28 \\
\hline Total & 0.24 & 0.18 & 0.58 & 1.00 \\
\hline
\end{tabular}

Based on the above assumptions, the traffic distribution for the new circulation plan is shown in Table 3. It is important to say that the anticipated volumes and turning counts for the new circulation plan are the "best" to be done given the limitations presented earlier in the first phase.

Table 3: Traffic Distribution Based on the New Circulation Plan (all day average)

\begin{tabular}{|l|c|c|c|c|c|}
\hline \multicolumn{1}{|c|}{ From\To } & Wadi Al Sir St. & Al Salt St. & Bassman St. & Al Sa'ada St. & Total \\
\hline Wadi Al Sir St. & 0.010 & 0.019 & 0.031 & 0.109 & 0.17 \\
\hline AL Salt St. & 0.163 & 0.010 & & 0.225 & 0.40 \\
\hline Ghazi St. & 0.071 & 0.112 & & 0.097 & 0.28 \\
\hline Bassman St. & 0.068 & 0.069 & & 0.015 & 0.15 \\
\hline Total & 0.31 & 0.21 & 0.03 & 0.45 & 1.00 \\
\hline
\end{tabular}

In reality, it is impossible to examine such estimates unless the new circulation plan is implemented and field counts are carried out. The volumes and turning counts on the various intersections are estimated as seen in Figure 5 showing morning; mid day; and evening periods, respectively. 


$\begin{array}{llll}\text { Al-Rafidain Engineering } & \text { Vol.21 } & \text { No. } 1 & \text { February } 2013\end{array}$

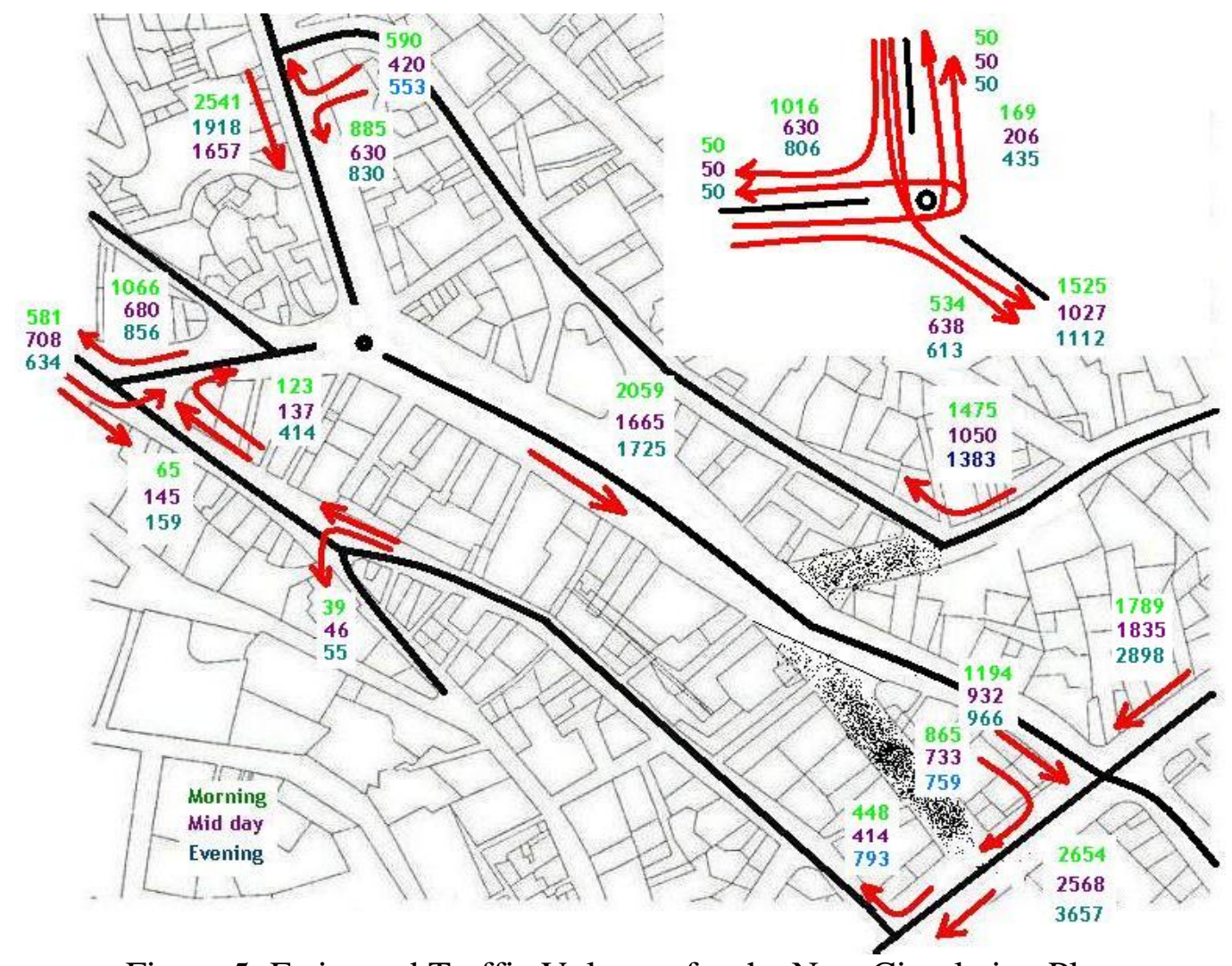

Figure 5: Estimated Traffic Volumes for the New Circulation Plan

\section{Traffic Modeling Results}

Based on the highway capacity manual (HCM, 2000), many modeling software packages were developed. The modeling processes are done at two levels; macro level and micro level using Synchro and SimTraffic software package (Husch, D., and Albeck, J., 2003). Various measures of effectiveness (MOEs) are used to describe the performance of the road network facilities at both of the macro and micro levels for each scenario.

At the macro level, the measures of effectiveness (MOEs) are intersection delay with the corresponding level of service (LOS), maximum volume to capacity ratio (v/c), and intersection capacity utilization factor (ICU). Such MOEs are used to compare among the various scenarios, the results are summarized in Tables 4 and 5.

Table 4: MOEs (Macro) for the Do-Nothing Scenario

\begin{tabular}{|c|c|c|c|c|}
\hline Intersection & Delay (sec) & Max. (v/c) & ICU & LOS \\
\hline \multicolumn{5}{|c|}{ Morning Period } \\
\hline AL Salt Street \& Faisal Street (signalized) & 98.2 & 1.36 & $121.3 \%$ & $\mathrm{~F}$ \\
\hline Faisal Street \& AL Shabsoogh Street (signalized) & 38.1 & 1.04 & $87.3 \%$ & $\mathrm{D}$ \\
\hline Faisal Street (Al Sa’ada) \& Talal Street (signalized) & 122.4 & 1.58 & $109.5 \%$ & $\mathrm{~F}$ \\
\hline \multicolumn{5}{|c|}{ Mid Day Period } \\
\hline AL Salt Street \& Faisal Street (signalized) & 23.7 & 0.93 & $83.6 \%$ & $\mathrm{D}$ \\
\hline Faisal Street \& AL Shabsoogh Street (signalized) & 22.2 & 0.91 & $78.1 \%$ & $\mathrm{C}$ \\
\hline Faisal Street (Al Sa'ada) \& Talal Street (signalized) & 135.9 & 1.58 & $115.7 \%$ & $\mathrm{~F}$ \\
\hline \multicolumn{5}{|c|}{ Evening Period } \\
\hline AL Salt Street \& Faisal Street (signalized) & 30.1 & 0.99 & $88.0 \%$ & $\mathrm{C}$ \\
\hline Faisal Street \& AL Shabsoogh Street (signalized) & 115.6 & 1.87 & $100.3 \%$ & $\mathrm{~F}$ \\
\hline Faisal Street (Al Sa'ada) \& Talal Street (signalized) & 204.9 & 2.39 & $141.0 \%$ & $\mathrm{~F}$ \\
\hline
\end{tabular}


Table 5: MOEs (Macro) for the New Circulation Scenario

\begin{tabular}{|c|c|c|c|c|}
\hline Intersection & Delay (sec) & Max. (v/c) & ICU & LOS \\
\hline \multicolumn{5}{|c|}{ Morning Period } \\
\hline AL Salt Street \& Ghazi Street (signalized) & 56.9 & 1.08 & $101.4 \%$ & $\mathrm{E}$ \\
\hline AL Salt Street \& Faisal Street (roundabout) & & 1.43 & $111.9 \%$ & \\
\hline Wadi Al Sir Street \& Bassman Street (signalized) & 15.2 & 0.88 & $71.8 \%$ & $\mathrm{~B}$ \\
\hline $\begin{array}{l}\text { Faisal Street (Al Sa'ada) \& Talal Street } \\
\text { (signalized), }\end{array}$ & 79.4 & 1.12 & $103.7 \%$ & $\mathrm{E}$ \\
\hline \multicolumn{5}{|c|}{ Mid Day Period } \\
\hline AL Salt Street \& Ghazi Street (signalized) & 13.2 & 0.89 & $76.8 \%$ & $\mathrm{~B}$ \\
\hline AL Salt Street \& Faisal Street (roundabout) & & 0.97 & 95.7 & \\
\hline Wadi Al Sir Street \& Bassman Street (signalized) & 8.6 & 0.68 & $53.8 \%$ & A \\
\hline $\begin{array}{l}\text { Faisal Street (Al Sa'ada) \& Talal Street } \\
\text { (signalized) }\end{array}$ & 50.3 & 1.04 & $97.2 \%$ & $\mathrm{D}$ \\
\hline \multicolumn{5}{|c|}{ Evening Period } \\
\hline AL Salt Street \& Ghazi Street (signalized) & 16.6 & 0.88 & $77.7 \%$ & $\mathrm{~B}$ \\
\hline AL Salt Street \& Faisal Street (roundabout) & & 1.25 & $113.6 \%$ & \\
\hline Wadi Al Sir Street \& Bassman Street (signalized) & 12.0 & 0.84 & $63.2 \%$ & B \\
\hline $\begin{array}{l}\text { Faisal Street (Al Sa'ada) \& Talal Street } \\
\text { (signalized) }\end{array}$ & 151.3 & 1.37 & $126.4 \%$ & $\mathrm{~F}$ \\
\hline
\end{tabular}

At the micro level, various simulation runs are applied for each scenario to insure the stability of simulation outputs. The following set of MOEs are recorded: average delay per vehicle (seconds), average stopped delay per vehicle (seconds), number of stops per vehicle, average speed (kph), fuel efficiency, and HC emissions. Table 6 summarizes the SimTraffic results. The overall performance of the new circulation plan is much better than the existing conditions. Tables 4, 5, and 6 are clearly indicating the superiority of the new circulation plan when compared to the existing circulation plan.

Table 6: SimTraffic MOEs for the various scenarios

\begin{tabular}{|c|c|c|}
\hline Micro MOEs & Do-Nothing & New Circulation \\
\hline \multicolumn{3}{|c|}{ Morning Period } \\
\hline Avg. delay/vehicle (sec) & 565.0 & 183.7 \\
\hline Avg. stopped delay/ vehicle (sec) & 557.1 & 178.2 \\
\hline number of stops/vehicle & 1.51 & 0.74 \\
\hline Avg. speed (kph) & 5 & 12 \\
\hline Fuel efficiency $(\mathrm{kpl})$ & 0.7 & 1.4 \\
\hline HC emissions (g) & 166 & 146 \\
\hline \multicolumn{3}{|c|}{ Mid Day Period } \\
\hline Avg. delay/vehicle (sec) & 254.1 & 95.8 \\
\hline Avg. stopped delay/vehicle (sec) & 248.2 & 89.5 \\
\hline number of stops/vehicle & 1.07 & 1.06 \\
\hline Avg. speed (kph) & 7 & 11 \\
\hline Fuel efficiency (kpl) & 1.1 & 2.1 \\
\hline HC emissions (g) & 98 & 93 \\
\hline \multicolumn{3}{|c|}{ Evening Period } \\
\hline Avg. delay/vehicle (sec) & 339.5 & 122.4 \\
\hline Avg. stopped delay/ vehicle (sec) & 333.3 & 115.0 \\
\hline number of stops/vehicle & 1.08 & 1.10 \\
\hline Avg. speed (kph) & 8 & 10 \\
\hline Fuel efficiency (kpl) & 0.9 & 1.8 \\
\hline HC emissions (g) & 132 & 117 \\
\hline
\end{tabular}


However, the most critical location is the intersection of Talal Street with Al Sa'ada Street, which is experiencing over capacity traffic on Talal Street, and therefore it is operating at LOS F. In this sense, a modified circulation plan is examined trying to improve the LOS at this location. The results were not good enough and the LOS remained unchanged (LOS F), even though the delay, max. (v/c), and ICU are improved.

The modified circulation plan utilized Al Reda'a Street for right turn south bound traffic in addition to serving pedestrians, leaving the through south bound traffic on Al Sa'ada Street. The results for that particular intersection are shown in Table 7 comparing the MOEs of the new circulation plan and the modified circulation plan for the evening period.

Table 7: Comparison of the MOEs at the Intersection of Al Sa'ada St. and Talal St.

\begin{tabular}{|l|c|c|c|c|}
\hline \multicolumn{1}{|c|}{ Plan } & Delay (sec) & Max. (v/c) & ICU & LOS \\
\hline New Circulation & 151.3 & 1.37 & $126.4 \%$ & $\mathrm{~F}$ \\
\hline Modified New Circulation & 100.0 & 1.20 & $108.5 \%$ & $\mathrm{~F}$ \\
\hline
\end{tabular}

\section{Conclusion}

In this research paper, six action plans were suggested: provide better pedestrian facilities; provide better parking facilities; organize loading and unloading operations; relocate terminals and public transport routes; propose new circulation plan for the study area; and relocate the Police Station on Faisal Street. Many preliminary circulation plans are tested targeting improving traffic safety and traffic operation proposing a new circulation plan. The new circulation plan was compared to the do-nothing circulation scenario (current circulation plan). Macro and micro measures of effectiveness are used to quantitatively compare between the two scenarios. Results showed notable improvements in favor of the proposed new circulation plan; however improvements are expected to be better if the demand implications of adopting the other actions were considered.

\section{References}

Alami, A.H., 2011, Traffic Flow Problem Simulation in Jordan, conference proceedings, Recent Researches in Engineering and Automatic Control ISBN: 978-1-61804-057-2 Published by WSEAS Press, www.wseas.org.

Al-Dmour, N. A., 2011, TarffSim: Multiagent Traffic Simulation, European Journal of Scientific Research, ISSN 1450-216X Vol.53 No.4, 570-575, EuroJournals Publishing, Inc. http://www.eurojournals.com/ejsr.htm.

Awad W. H., 2012, Traffic Assessment of Faisal Street Down Town Amman City, Transnational Journal of Science and Technology, April 2012, vol. 2, No. 2.

Dowling, R., Margiotta, R., Cohen, H., and Elias, A., 2011, Methodology to Evaluate Active Transportation and Demand Management Strategies, Procedia - Social and Behavioral Sciences, Volume 16, 751-761.

Greater Amman Master Plan, 2012, http://www.ammancity.gov.jo/../GAM_strategy.pdf.

Highway Capacity Manual, Transportation Research Board, Washington, DC, 2000. 
Husch, D., and J. Albeck. 2003. Synchro 6, Traffic Signal Software-User Guide. Trafficware Corporation, Albany, Calif.

Kelly, E.D., 2010, Community planning: An introduction to the comprehensive plan, second edition, Island Press. ISBN-13:978-1-59726-552-2.

Thompson, Ryan E Suter, Sonya N., 2012, Developing Standard Performance Measures for Transportation Demand Management Programs, Transportation Research Board 91st Annual Meeting, Washington DC, Transportation Research Board.

TSUBOHARA, S. 2007, The effect and modification of the Traffic Circulation Plan (VCP), Urban and Regional Studies Institute, Research Report 317.

Wonkyu, K., Jaesung, P., Youn-Soo, K., Gyeong P., and Hyeonmi, K., 2010, Comparing Calibration Methods for Microscopic Traffic Simulation Models, Proceedings of the 17th ITS World Congress, Busan. 